\title{
Dressing after Dressing: Sadra’s Interpretation of Change
}

\author{
Muhammad Kamal \\ Asia Institute, The University of Melbourne, Melbourne, Australia \\ Email: muhammad@unimelb.edu.au
}

Received October 22 ${ }^{\text {nd }}, 2012$; revised November 25 ${ }^{\text {th }}$, 2012; accepted December $10^{\text {th }}, 2012$

\begin{abstract}
This paper deals with the doctrine of transubstantial change advocated by Mulla Sadra in which substances as well as accidents are thought to be in constant and gradual change. Against Aristotle's doctrine of accidental change, Mulla Sadra argues that no stable ground can bring about change and since substance is renewable it cannot carry identity of a changing existent. Here we investigate whether identity is possible or not. If it is possible then what becomes a ground for establishing identity of changing substances.
\end{abstract}

Keywords: Ontology; Existence; Essence; Change; Substantial Change; Accidental Change; Identity and Difference

\section{Sadra's Ontology}

While Muslim Peripatetic thinkers under the influence of Aristotle accepted change in accidents, Mulla Sadra insisted on change in substance. For him, change in accidents is thinkable when substance undergoes change and transformed. Here I intend to analyse Mulla Sadra's doctrine of transubstantial change. I also examine how the implications of this doctrine have drastic consequences on the identity of a changing existent, and discuss the possibility of establishing identity without relying on substance in Mulla Sadra's ontology.

Sadr al-Din Muhammad b. Ibrahim b. Yahya Shirazi Qawami, (1572-1640), also known as Mulla Sadra, like Shahab AlDin Suhrawardi (1155-1191) and his teacher Mir Damad (d. 1631), believed that "essence" was real and stood as the ontological principle of all existents. But his discontent with this doctrine made him alter his position and became the defender of the doctrine of the principality of "Existence". As described by him, this change in attitude was the outcome of a mystical experience and divine guidance stating that, "In the past, I used to be firm on the defense of the principality of essence, making existence a [mentally dependent] abstract entity, until my God guided me and showed me his proof. It became clear to me that the issue is the opposite of what has been conceived and determined. Thank God who took me out of the darkness of illusion through the light of comprehension, who removed from my heart the clouds of these doubts through the rise of the sun of truth, and who held me close to the true discourse in this life and the life after. Existences are genuine [determinate] realities and essences are the eternal "thisnesses" which have never inhaled the perfume of real existence at all. These existences are merely the rays and reflected lights of The True Light and of the Eternal Existence. Exalted Be His Sublimity! However, each of them has essential predicates and contains intelligible concepts called essences ${ }^{1}$.

${ }^{1}$ Mulla Sadra \& Muhammad b. Ibrahim (Sadr al-Din) Shirazi (1992), alMasha'ir, translated by Parviz Morewedge, New York, p. 43. Mulla Sadra (1999), al-Asfar al-Arba'a, 1, 1, Beirut: Dar Ihya'al-Turath al-'Arabi, p. 9. See also, Mulla Sadra, (1981), al-Shawahid al-rububiyyah, Tehran: University Publication Centre, pp. 50-51.
Contrary to Suhrawardi's ontological position, Mulla Sadra does not accept the idea that "Existence" is unreal or that it is a mental concept. For him, "Existence" is an objective reality and the principle of all things. Its reality encompasses the lowest and the highest. At the highest it is the existence of the Necessary Being. At the same time, "Existence" is different from existents and transcends all logical categories and definitions, for the simple reason that "Existence" has neither a genus nor differentia ${ }^{2}$. This philosophy inaugurates a new system of ontology in which the theme of inquiry is "Being" as such, and philosophy becomes the science of Being or ontology. Mulla Sadra re-asserts this point in al-Masha'ir stating that "The question of existence is the foundation of the principles of wisdom, the basis of philosophical theology, and the nexus of [concern] of those in the circle [lit. the mill-stone, i.e., the centre] of the sciences of unity, the resurrection of souls and bodies, and of much else that only we have developed and articulated. It gives them a synthesis [lit. a unity] through its explanation. Anyone who is ignorant of the gnosis of existence is also ignorant of the major [lit. mother] subjects and most significant quests, misses the refinements of gnosis and its subtleties, the science of the divine and the prophets, the gnosis of the soul, and its connection and return to the [primordial] source and destiny [i.e., telos]. We therefore open this treatise on the principles of the truths of faith, principles of wisdom and gnosis”3. Philosophy qua ontology is engaged with an understanding of the meaning of "Existence" rather than existents and "Existence" is a nucleus around which all other philosophical issues revolve. The oblivion of "Existence" will affect our understanding of other philosophical issues because "Existence" as the sole reality and basis for all existents pushed to the background.

In light of the principality of "Existence", any discussion determining the nature of the relationship between existence and essence seems irrelevant. For, existence is identical with essence in the external world, and the difference between them arises in thinking. The dichotomy between existence and essence is conceptual and exists only in the mind. When we are

\footnotetext{
${ }^{2}$ Mulla Sadra, al-Asfar, 1, 1, p. 50

${ }^{3}$ Mulla Sadra, al-Asfar, Vol. 1, p. 24. See also Mulla Sadra, al-Masha'ir, pp.
} 3-4. 
asked about the essence of an existing-entity we analyse its universal determinations and distinguish them from its existence. For example, the existence of a table is in thinking is different from its being brown and round. It is through our analysis that we separate the existence of the table from its essence and insist on the principality of one of them over the other. Essence is a product of our conceptual analysis, having no reality of its own. When we employ logical categories to describe or define an existent, "essence" rather than "existence" is realized and we do not talk about its existence. We do not say that "The table is an existent," but "It is brown and round." Mulla Sadra has no problem with this view as long as "essence" is described as the product of intellectual consideration, and is only in thinking, "From the mental point of view, however, the prior factor is essence, because it is a universal mental notion which is realized in its [deep-seated sense] of being in the [mental realm]; it is not obtained [in the mode of being concrete] from existence, except in a general and mental concept" ${ }^{\text {. }}$. Essence is a determinate factor in the intellectual process and the abstract conceptual activity of thinking. But it has no ontological reality by itself and at the same time cannot exist outside thinking. It is the principle factor in thinking but not in the external world. This priority of essence in this respect is a priority in meaning rather than a priority in existence. It is also not a priority in terms of causality or temporality because essence cannot become the cause of existence and does not precede it in time. There is nothing but "Existence", and the modification of "Existence" in different forms. Each form represents a particular manifestation of "Existence". The relation between "Existence" and its resultant forms is like that of the ground with the grounded. "Essence" cannot be independent of "existence" except in thinking. This can also be refuted as for something to be in thinking is itself a mode of existence or it is something that exists in the intellect. Even in this case "essence" is inseparable from existence.

In making the distinction between "Existence" and its modes, there is an emphasis on purity and simplicity of "Existence", while the modes of "Existence" are described as composite entities. The simplicity of "Existence" is an ontological prerequisite for its principality because every composite existence presupposes prior existence of its components. For this reason, we cannot think about the existence-essence relationship at this ontological level of "Existence". "Existence", qua reality, is the realm of simplicity. Dualism or Existence-essence dichotomy arises when an existent is intellectually analysed but in reality what we experience and confront is mere existence. Dualism is not found in the world, but only in thinking. Intellectual analysis is applicable only to the modes of "Existence". It is impossible to apply it to "Existence" because it is pure, simple, and has no quiddity otherwise it does not become the ontological principle for the multiple existents in the world.

In this ontology change is also seen as real and the existentialist characteristic of the world. It is the process of the selfdisclosure of "Existence" in which emanation of the lower ranks of existence, the rise of multiplicity and the gradation of "Existence" together become possible. But the notion of change in Mulla Sadra's ontology includes substance as well as accidents.

Mulla Sadra has come with a new interpretation of change with significant implications on the concept of identity carried

${ }^{4}$ Mulla Sadra, al-Masha'ir, (The Metaphysics of Mulla Sadra), p. 38. by substance. Against Aristotle’s doctrine of accidental change he argues that a stable and enduring ground such as substance cannot bring about change in its own accidents as accidents do not exist independent of substance alteration in the accidents should be seen as the result of change in substance and not vice versa, "The renewal of the source, therefore, certainly brings about the renewal of the effects" ${ }^{5}$. Aristotle approved of change in the categories of quality, quantity, position and space, while "substance" remained durable simply because there was no contrary to it ${ }^{6}$. An individual substance, Socrates for example, would go through accidental changes. He becomes a philosopher or a father but his "essence" does not change. Aristotle built his theory of change on the foundation of Plato's metaphysics dualism and made a sharp distinction between what was changeable and what was not in all existents. There are metaphysical roots to this analysis based on the conviction that accidental change requires a clear distinction between a substrate: something stable and something in transition. By contrast, Mulla Sadra's ontology is a monism, in which change becomes a characteristic of reality. The flow of emanation is a process where multiple existents become manifest. This ontological monism accommodates multiplicity and turns out to be the foundation for the principle of unity in multiplicity or multiplicity in unity. Emanation of the modes of "Existence", the gradation of "Existence" and identity in difference are all grounded in the principality of "Existence" and direct our discussion to the notion of change.

When we examine the doctrine of the principality of "Existence" and the belief that "Existence" encompasses all existents, we realize that "Existence" is used univocally (common to all) as well as equivocally (different in each case). It is the principle of identity and difference. To attribute identity to "Existence' and difference to something else is a contradiction because in this ontological system there is nothing other than "Existence". The modes of "Existence" represent its gradation and gradation signifies the difference that arises within the unity of this reality. A particular existent shares the same reality with other existents and at the same time it is different from them. All existents are also different from "Existence". The presence of all existents is the outcome of the self-manifestation of "Existence" in the actual world. The truth of "Existence" is in one way a unity, which becomes the foundation for ontological monism. This unity has also internal multiplicity and gradation. The very same reality that is shared by all existents is that by which they are different from each other. This truth is demonstrated by the self-manifestation of "Existence" and cannot be grasped without thinking about change.

As mentioned earlier, Muslim Peripatetic thinkers accept Aristotle's doctrine of accidental change, which includes change in the four categories of quality, quantity, position and space. The accidental change is also described as a gradual increase or decrease in the intensity of the quality and quantity, or a gradual shift in position and finally locomotion. But all these categories belong to substance, which is itself a category with distinct characteristics. One of the peculiar characteristics of substance is unchangeability. A careful examination of Aristotle's philosophy will reveal that even substance is changeable, but in

${ }^{5}$ Mulla Sadra, (2010), al-Asfar, 3, stage 7, chapter 20, translated by Mahdi Dehbashi, London: ICAS Press, p. 104.

${ }^{6}$ Aristotle, (1995), "Categories", 4a 10-20, in Complete Works of Aristotle, vol. 1, (ed.) Jonathan Barnes, Princeton, New Jersey: Princeton University Press. 
a different way. It is sudden and not gradual, and is described as generation (coming into existence) and degeneration (ceasing to be). There is no room for a continuous and gradual change in substance the way it occurs in its accidents ${ }^{7}$. Mulla Sadra rejects this doctrine and holds the view that an immutable substance is not capable of generating change in its own accidents. Accidental change requires substantial change, "When we talk about motion within the categories, there are four ways in which this can be done: first, any category (maqulah) may be a real subject of the motion; second, substance by means of a category is the subject of motion, even though it is a substance; third, any category is a genus of motion; fourth, substance is transformed and changed gradually from one species of the category to another or from one class within the category to another. The latter is the correct alternative to the exclusion of the others"8. In addition to this, and in order to communicate his own position, Mulla Sadra expresses discontent with three possibilities of change and chooses the fourth possibility as valid. In the first possibility the categories of quality, quantity, position and space are seen as subjects to change and not limits within which change occurs. They become entities rather than properties of the individual substances. With this analysis we end up with Aristotle's distinction between what is changeable and what is not within them, "In the first assumption we say that it is not the nature of black which gradually intensifies. If the nature of black, therefore, remains unchanged and no property is added to it and so it is not intensifies, then it remains exactly as it was before. But if a black thing undergoes any accidental change in its color and if the nature of blackness remains unchanged, then no transformation takes place in that nature."9 It should be remembered that Mulla Sadra does not deny change in accidents, he has problem with accepting stability in substance. For him the possibility of accidental change is preconditioned by substantial change. In what follows, and contrary to the position of Aristotle and Muslim Peripatetic philosophers, there is no dichotomy of immutable and mutable in the process of change. Neither accidents nor substance can escape change.

The doctrine of transubstantial change is also based on the conviction that every individual substance is a composite of potentiality and actuality. This is true because a substance in the physical world is the combination of matter and form. As long as a substance is composite and corporeal it will go through change from potentiality to actuality. In al-Masha'ir this point is re-stated and change is attributed to corporeal substances only, "This is substantial form as it applies to bodies; it is the proximate principle concerned with essential movement [of the body], and its rest and the source of its effects. There is no body except that which is necessarily constituted by this formal substance which is embedded in all its components, namely that it is always in a state of modification, renewal, being cut, disappearance, and destruction"10. Change becomes problematic with incorporeal substances, as they are simple and pure actuality. Whatever is pure actuality is not subject to change because it has no potentiality and privation. In the world of generation and degeneration there is nothing that corresponds to pure actuality. Every existent is a composite of potentiality and actuality. Change is impossible for an existent that is actual in all respects and is without potentiality. Think-

\footnotetext{
${ }^{7}$ Aristotle, "Physics”, 190a 1-30, in Complete Works of Aristotle, vol. 1.

${ }^{8}$ Mulla Sadra, al-Asfar, 3, stage 7, chapter 22, p. 111.

${ }^{9}$ Mulla Sadra, al-Asfar, 3, stage 7, chapter 22, p. 118.

${ }^{10}$ Mulla Sadra, al-Asfar, 3, stage 7, chapter 19, p. 98.
}

ing about change as an existential reality of all corporeal substances and transformation from potentiality to actuality will exempt non-corporeal substance from change. Mulla Sadra accepts the existence of non-corporeal substances, and calling them "rational substances". These two kinds of substances are ontologically as well as existentially connected and seem inseparable, "The relation of that rational substance to this bodily nature is that of perfection and imperfection, of root to branch"11. Again these rational substances should not be mistaken for Plato's universal forms. They are ideas in God's knowledge and become actually existents when they are emanated and transformed into materialized forms in the world. This also means that these substances existed eternally as ideas in God's knowledge. Their temporality is related to their presence in the material world and their temporal emergence through the effusion of God. According to this analysis, the subject of change is always corporeal or a body composed of matter and form. Every existent that admits change has something potential in it, which means that it pursues something that is not yet actualized. There has to be potentially something for which change takes place. An existent that admits change is therefore a substance composed of potentiality and actuality, matter and form. Corporeal substances, unlike their counterparts, are loaded with potency and are capable of being actual. As long as they carry potency, their existence will have a certain degree of privation, and they endeavor to achieve perfection through the gradual process of transubstantial change. Nothing in the material world, even the substrate of Aristotle, perdures under the sway of change.

\section{Arguments for Change in Substance}

Mulla Sadra developed three arguments for change in substance. The first argument is on the dependence of accidents on substance. The second relies on the relation between cause and effect. The third argument is borrowed and based on the views of Suhrawardi on change. In addition to these three primary arguments, Dehbashi mentions five secondary arguments, which are derived from the first argument. One of these arguments is not philosophical but religious and reflects on the Qur'anic conjectures. Against Aristotle's doctrine of accidental change, which is based on the doctrine of metaphysical dualism, Mulla Sadra insists that there will be no accidental change without substantial change and states that, "Accidents, however, are existentially dependent on the existence of formal substances. But, as you know, motion itself has no reality except as continuous renewal and transformation (taghyir) of some entity; it is not itself an entity, because motion is precisely the relation of renewal, not an entity on which renewal depends"12. Accidents are ontologically as well as existentially dependent on substance. What is accidental is necessarily substantial. All accidental changes, therefore, should be subordinated to substance simply because accidents have no reality of their own. It is the continuous renewability of substance that brings about change in accidents. Only with the idea of the mobile nature of substance one can understand change in accidents. This argument can be analyzed in two ways. On one side, accidental change cannot be generated by accidents as they do not exist by themselves. Their existence is very much part and parcel of substance. Every kind of change in accidents is generated by sub-

\footnotetext{
${ }^{11}$ Mulla Sadra, al-Masha'ir, (The Metaphysics of Mulla Sadra), p. 81.

${ }^{12}$ Mulla Sadra, al-Asfar, 3, stage 7, chapter 25, p. 154.
} 
stance. On the other side, the argument is dealing with the dependency of accidental change on substantial change. Accidental change does not take place without change in substance because all accidents belong to substance. Mulla Sadra also defines substance as "nature"; for example, he states that, "Philosophers such as Ibn Sina (and others) showed that nature, insofar as it is not in process, cannot be a cause of motion"13. Here, for Ibn Sina and other Muslim Peripatetic philosophers, nature or substance remains unchangeable. Sabzavari, in his commentary on the meaning of "nature" in this context, identifies it with the divine agent that becomes the ontological foundation of every individual existent ${ }^{14}$. In this manner, change in substance is the transformation of nature of an existent. A small and solid seed of a plant changes into a soft fruit. Its softness, which is an accidental change, is indicative of the ripeness of its nature or substance. The seed accomplishes this stage of perfection through change in its nature. Now, the actual fruit is no longer the seed, which was potentially a fruit. This perfection cannot be achieved without change in the nature of this existent.

The second argument is focused on the relation between cause and effect and the similarity in their properties. If we think of substance as the cause of change then it should be similar to its effect. We cannot say it is stable otherwise there would be no similarity in their properties. It is not possible for a cause to be stable while its effect is unstable. Here, Mulla Sadra rejects the position of the Muslim Peripatetic philosophers and states that, "Finally, the sum total of renewals, as effects, comes to an end in nature as cause. The renewal of source, therefore, certainly brings about the renewal of the effects"15. The dynamic characteristic of effect, the accidental change is grounded in the change in the cause of it. There is no change in effects without change in their cause. The relation of substance to change will be seen as necessary. According to Dehbashi, the necessary relation between cause and effect becomes a subargument for the vindication of the transubstantial change ${ }^{16}$. This could be interpreted in two ways. First, since the relation between cause and effect is logically necessary, in the sense that there is no cause without effect and no effect without cause, there will be no change without substance. Second, we understand that a changing substance is a composite of potentiality and actuality and suffers privation in one way or another in its existence. Existentially, and by nature a corporeal substance requires change in order to overcome its own privation and reach perfection.

The third argument is called "The Illuminationist Proof for Transubstantial Motion" and based on the unity of accident as a noun (i.e., blackness) with accidental as an adjective (i.e., black). Mulla Sadra remarks that "Every corporeal substance has a mode of existence such that some of its accidents are necessary and inseparable from it. These accidents are related to the individual in the same way as the accidental properties of derived differentiae are related to species. Most philosophers call these inseparable accidents "specific differences". But as a matter of fact they are signs of specific differences. Here the signs are a token of something interpreted conceptually. Thus derivative real differences are interpreted conceptually by logical difference" ${ }^{\text {"17 }}$. Here the real distinction between "accident"

\footnotetext{
${ }^{13}$ Mulla Sadra, al-Asfar, 3, stage 7, chapter 20, p. 108.

${ }^{14}$ Mulla Sadra, al-Asfar, 3, stage 7, chapter 20, p. 104.

${ }^{15}$ Mulla Sadra, al-Asfar, 3, stage 7, chapter 20, p. 107.

${ }^{16}$ Mulla Sadra, al-Asfar, 3, p. 79.

${ }^{17}$ Mulla Sadra, al-Asfar, 3, stage 7, chapter 26, p. 167.
}

and "accidental" is denied; rather, the distinction between them is conceptual and resembles the logical distinction between genus, differentia, matter and form. The denial of the real distinction between "accident" and "accidental" outside thinking unites both of them and at the same time establishes a necessary relation between them. But the question that arises here is how can this unity be employed for the justification of transubstantial change? After establishing this unity between "accident" and "accidental" Mulla Sadra turns to the necessary relation between accidents and their corporeal substances and then to the relation between accidental and substantial changes. For him the relation between accidents and substances is similar to that of differentia to species. When two things are necessarily connected the change in one of them affects the other. In this case, the change in accidents is identical to the "accidental" change. Since the accidents are necessarily connected with substances the accidental change is identical to the change in substance.

These are the main philosophical arguments developed by Mulla Sadra. There are other arguments or sub-arguments also mentioned by Dehbashi, but not all of them are philosophical. One of these arguments relies on a doctrine of the mystic tradition, advocating constant transformation of the archetypes, such as the human beings, to achieve perfection. Another is religious and based on Qur'anic conjectures. The religious argument is an attempt to justify his doctrine of transubstantial change on the grounds of faith. He quotes a number of Qur'anic verses where the notion of change is cited: "On the day when the earth changed into a different earth and the heavens into new heavens, mankind shall stand before God, the One, who conquers all”18; "The mountains, firm though you may think them, will pass away like clouds. Such is the might of God, who has perfected all things. He has knowledge of all your actions"19; "Were We worn out by the First Creation? Yet they are in doubt about a new creation” ${ }^{20}$. There are still more verses that allude to the change in substance or the transformation of nature ${ }^{21}$. This argument, however, relies totally on the Qur'anic verses as evidence rather than logical arguments.

As we know a number of Sufis such as Ibn'Arabi (11651240), Jalal al-Din Rumi (1207-1273), Shaykh Mahmud Shabistari (1288-1340) and others, believed that the archetypes were in constant renewal towards reaching perfection. The mystic doctrine is also called the renewal of the images, meaning that every existent is in constant renewal in the form of dressing after undressing. The changing existent is annihilated and receives a new existence based on the image of its previous existence. No existent will ever continue between two moments of change. The doctrine of transubstantial change is different from that of the mystics in four ways. First, Mulla Sadra's doctrine is not purely mystical. It is philosophical too and supported by logical arguments. Second, the change in substance as well as accidents is existential because "existence" and not "essence" is the sole reality. There is no distinction between substance and its existence. We cannot say that existence is something added to substance when they were emanated, "Transformation of quantity, colour, or position, therefore,

\footnotetext{
${ }^{18}$ Qur'an 14:48.

${ }^{19}$ Qur'an 17:88

${ }^{20}$ Qur'an 50:15

${ }^{21}$ Mulla Sadra, al-Asfar, 3, stage 7, chapter 26, 178-79. For the translation of these Qur'anic verses into English I have used N. J. Dawood's translation of the Qur'an published by Penguin Books in 2003.
} 
necessitates transformation of the bodily, substantial, and individual existence. This is what we mean by transubstantial motion. Substance is the existence of substance, and accident is the existence of accident”"22. Third, it seems that the Sufi doctrine does not make a distinction between corporeal and non-corporeal substances and keeps both of them under the influence of change. By contrast, Mulla Sadra's doctrine ascribes transubstantial change only to the corporeal substances, "The first existence is worldly, temporal, corruptible, and capable of destruction and without any stability at all. The second is perduring in God's presence, incorruptible and incapable of destruction because whatever is known to God, the Exalted, [in his exemplary idea] cannot be eliminated; that is to say, the knowledge of God, the Exalted, cannot be changed"23. Based on this distinction between two kinds of substances there will be no total annihilation of an existent when it goes from one stage of change to another. Fourth, dressing after dressing (labs ba'da labs) explains the renewal of substance under the influence of successive changes towards accomplishing perfection. In this process, substance, like its own accidents, does not persist in the same state of existence. The change in substance, at the same time, does not result in the annihilation of the previous substance. It is preserved and elevated, which is described as dressing after dressing.

\section{Characteristics of Transubstantial Change}

Transubstantial change is an indication of privation and imperfection of all corporeal existents which are embedded in relative nothingness. Privation in the world is caused by variation in intensity of existence, which also gives rise to multiplicity. The degree of intensity of existence is different from plants to animals and from an embryo to an adult. For this reason, each corporeal existent is conditioned by change and determined by its end. The idea of transubstantial change, therefore, presupposes the state of imperfection in every existent. It should also be remembered that there is no "absolute" privation as every corporeal substance is composite of potentiality and actuality and it is an existent. In transubstantial change the agent of change and the changing existent are not two different things. Substance changes internally and this gives rise to accidental changes eventually. The agent of change is inherent in the corporeal substance. In this case the agent of change will be substance itself or the mover and the moving body will be identical. ${ }^{24}$ More specifically, the agent of accidental change is substance and the agent of substantial change is the existence of substance. This identification of the agent and object of change is based on Mulla Sadra's attempt to identify potentiality with actuality, "Whatever is potential is exactly the same as that which is actual"25. Potentiality contains actuality and vice versa. Potentiality is implicitly an actuality and every actuality becomes potentiality for attaining another actuality. This process continues until an existent arrives at the level of pure actuality and the stage where it has no more potentiality to carry out another actuality.

Transubstantial change is transformation of an existent from imperfection to perfection or from a lower level to a higher level of perfection. Evolution becomes the characteristics of

\footnotetext{
${ }^{22}$ Mulla Sadra, al-Asfar, 3, stage 7, chapter 26, p. 169.

${ }^{23}$ Mulla Sadra, al-Asfar, 3, stage 7, chapter 26, p. 170.

${ }^{24}$ Mulla Sadra, al-Asfar, 3, stage 7, chapter 19, pp. 98-99.

${ }^{25}$ Mulla Sadra, al-Asfar, 3, stage 7, chapter 19, p. 100.
}

this movement. Every existent travels on its path towards perfection as part of an evolutionary process. For example, in human existence evolution aims at the perfection of human beings (al-insan al-kamil). Mulla Sadra describes this end as the ultimate objective achieved when a human being is unified with the "Active Intellect", "If man achieves the highest degree of knowledge and perfection, he reaches the rank of The Active Intellect on which depends the establishment of the Good and Generosity. It connects to its primordial [state], [which is] the last circle of existence" ${ }^{\text {26 }}$. The idea of perfect human being is essential in Mulla Sadra's spiritual psychology, coming originally from Ibn'Arabi's theosophy. It explains the purpose of human life and the end of the spiritual journey undertaken by those who aim at attaining reunion with God. Under the influence of this Sufi notion and in light of transubstantial change, Mulla Sadra points out the purpose of change in human existence saying, "We have explained earlier that all the existents in this world are traveling towards God the Exalted, but they are unaware of it due to the thick veils [of ignorance over their souls], and piling up of darkness over them. But this essential movement, and this journey towards God the Exalted is more evident and manifest in man, especially in a Perfect man who crosses all these [levels] of ascending arc."27 Here, the evolutionary character of transubstantial change is progress towards the richer states of existence. This progression can be compared with the dialectic movement in Hegel's logic where movement is described as progress in which every new moment is richer than the previous one. An antithesis, for example, does not annihilate or destroy its thesis but elevates it. Their synthesis contains both of them. The evolutionary character of transubstantial change is not capricious or erratic but intentional and systematic. It is determined by an increase in intensity of reality. Everything that goes through transubstantial change is a mode of "Existence" and hence conditioned by "Existence" ontologically. This makes change teleological, by seeking perfection through undertaking a journey towards the origin.

Another characteristic of transubstantial change is related to identity. Since substance is changeable it will be impossible to establish the identity of an existent on it. At every moment of change substance is continuously renewed and has a different identity, "And so you have come to understand that the proximate agent of motion is some continuous renewal of identity. If it were not so, it would be impossible for these natural motions to come from it, that is, from the perduring." ${ }^{28}$ Here one can talk about identities rather than a single identity, or we can say that transubstantial change generates a stream of identities until the changing existent arrives at a level where no more change in substance and formation of a new identity is required. The

\footnotetext{
$\overline{{ }^{26} \text { Mulla Sadra, al-Masha'ir (The Metaphysics of Mulla Sadra) 88. See also: }}$ Mulla Sadra, (1999), al-Mazahir al-ilahiyya, edited and annotated with an introduction by S. Muhammad Khamene'i, Tehran: Sadra Islamic Philosophy Research Institute (SIPRIn) publication, p. 65. Mulla Sadra got the idea of perfect human being from Ibn'Arabi; in al-Asfar he states that, "The Gnostic Shaykh [Ibn'Arabi], the author of al-Futuhat al-Makkiyya, The Makkan Openings, chapter three hundred and sixty one says that he intended to explain that the Perfect man is the vicegerent of God, and is created in the [noetic] Form of the Compassionate.” See: Mulla Sadra, al-Asfar, 8, chapter 3, in Spiritual Psychology, the Fourth Intellectual Journey in Transcendent Philosophy, vol. 8-9, translated, annotated, and introduced by LatimahParvin Peerwani, (2008) with foreword by Sayyed Khalil Toussi, London: ICAS Press, p. 121

${ }^{27}$ Mulla Sadra, al-Asfar, 8, chapter 3, in Spiritual Psychology, the Fourth Intellectual Journey in Transcendent Philosophy, p. 387.

${ }^{28}$ Mulla Sadra, al-Asfar, 3, stage 7, chapter 20, p. 103.
} 
renewal of identities is also called "dressing after dressing" (labs ba'da labs), and Mulla Sadra refers to the Qur'an to authenticate his view, "Were We worn out by the First Creation? Yet they are in doubt about a new creation, ${ }^{\text {,29 }}$. But this idea of constant renewal, unlike that of the Muslim Sufis, does not entail the total annihilation of the previous form and the generation of something absolutely different. In transubstantial change renewal is continuity, meaning that the newly generated forms are different and at the same time connected with the previous forms. The previous forms become a podium for the generation of the new forms and both of them are existentially connected and the same. With the idea of "constant renewal" transubstantial change can be seen as "constant becoming". All existents at the level of microcosm as well as macrocosm in the material world change substantially. They are generated and degenerate in time. "Becoming" is, therefore, another aspect of the reality of "Existence" through which the modes of "Existence" come into existence in the lower grades of existence in the material world and then ascend to their archetypal states of existence.

From the characteristic of "Becoming" we arrive at the notion of "perpetual creation". Becoming is the self-manifestation of "Existence", which leads to the creation of the material world. In this process all corporeal substances are generated and degenerate. They travel through various degrees of perfection in two different directions: descending and ascending. These two directions correspond to an increase and decrease in intensity of "Existence". The self-manifestation of "Existence" in these two directions never ends and is an interruptible act of creation. These characteristics of the transubstantial change cannot be understood independently. They are necessarily related in that the detection of one of them will lead to the other. This does not mean that we interpret their relation in terms of priority and posteriority because all of them are equally important. Neither do we ascribe necessity to them in the sense of causality and think that the second characteristic is a sequence of the first. By arriving at the characteristic of "perpetual creation" through the characteristic of "constant renewal”, for example, no causal relationship is involved. The necessary relation between these characteristics signifies that the disclosure of one of them sheds light on the others and the truth of one of them inevitably validates the truth of the other characteristics.

\section{Transubstantial Change and the Principle of Identity in Difference}

Generally, there are four assumptions regarding change. The first assumption is the denial of change, and represents the views of Parmenides and other Eleatic thinkers. The second assumption positions everything in the state of flux, and represents Heraclitus's interpretation of reality. Third is the assumption that not everything but only accidents change. Substance, unlike accidents, remains stable. This was the view of Aristotle and Muslim Peripatetic thinkers. The fourth assumption is apparently consistent with the second assumption but attributes change to substance as well as accidents. This assumption is the dominant feature of Mulla Sadra's interpretation of change. Our concern is not the problem of identity with accidental change. Change in accidents does not result in a change in the identity of an existent simply because substance, which is thought to be unchangeable, carries identity. This Aristotelian interpretation

\footnotetext{
${ }^{29}$ Qur'an 50:15.
}

of identity, which corresponds to the third assumption, is rendered invalid when change is attributed to substance and identity becomes problematic. A careful examination of Mulla Sadra's ontology will help us to understand that even with transubstantial change something endures providing a certain type of identity to whatever is in transition. What is this stable entity underlying change in substance? If everything changes, including substance, then what are the grounds of identity? As far as identity is concerned there is a certain degree of perplexity in Mulla Sadra's philosophy. On one side we can describe his ontology as existential monism standing against metaphysical dualism inherited from Plato. On the other side, Mulla Sadra draws a distinction between corporeal and incorporeal substances, convincing us to believe in the presence of a stable entity beneath the surface of the changeable world. Does this mean that Mulla Sadra has not been able to liberate himself from Plato's tradition and in particular the doctrine of metaphysical dualism? With these questions our analysis of his ontology and the doctrine of transubstantial change require a fresh examination of the principle of identity. This task will also necessitate proper investigation into the ontological foundation of identity.

With the doctrine of transubstantial change the problem of identity proves itself to be important in Mulla Sadra's ontology. Without identity there can be no unity within the existence of an entity in flux over time, "In general, every material object, whether it is the material of the stars or the elements, whether soul or body, constantly require new identity and its personality and its existence is never fixed”30. In thinking about identity of an existent at different moments of change we deal with the binary relation that holds this existent to itself; for this reason and here we are not concerned about identity between two entities. If we believe that an existent goes through substantial change then the changing existent cannot be one and the same thing before and after change. The same existent must be different. Does this mean that identity of an existent at the first moment of change is destroyed and another one is created temporarily? The problem of identity can be traced back to Parmenides's ontology, "The one-that [it] is, and that [it] cannot not be" ${ }^{\text {} 1}$. Later Aristotle developed this notion of Parmenides's in his logical system into the principle of identity or non-contradiction and it became one of the rules of thought upon which rational discourse itself was based. Aristotle, in De Interpretatione, states that, "For if every affirmation or negation is true or false it is necessary for everything to be the case or not to be the case."32 This statement confirms the law of identity and rejects contradiction in a single statement. In the truth of an expression, such as $\mathrm{A}$ is A cannot be otherwise at the same time. It is not possible to say that A is A and not A. Thinkers such as Spinoza and Hegel modified the law of identity as they believed that the Aristotelian law was abstract and excluded the difference. For them, every determination was at the same time a negation. For example, a proposition such as, "The table is black," means that it is not white. Every affirmative proposition or judgement contains its opposite (negation) implicitly. Transubstantial change signifies that the modes of "Existence", in particular those attached to matter, from the

\footnotetext{
${ }^{30}$ Mulla Sadra, al-Masha'ir, (The Metaphysics of Mulla Sadra), p. 80.

${ }^{31}$ David Gallop (1984). Parmenides of Elea, fragments, a text and translation with an introduction, Toronto, Buffalo, London: University of Toronto Press fragment 2.5, p. 55 .

${ }^{32}$ Aristotle, "De Interpretatione", 18a1, 35, in Complete Works of Aristotle, Vol. 1.
} 
perspective of their identity are in a state of flux. Since all material existents are modes of "Existence", one way of establishing their identity is through the principality of "Existence". Based on this ontological doctrine a changing existent remains the same in regard to its "existence" at two different moments. The substance and accidents of an existent undertake change but its existence will continue. If "existence" of the changing entity is annihilated and a new "existence" (not a new substance) is created then nothing will remain as the unifying principle between the two moments of change in the same existent. The existence that undergoes change becomes non-existence and consequently a totally different entity will come into existence. We also know that existence is neither a substance nor accidents. It encompasses all of them and subsists as the changing entity does not cease to exist while it goes through change. ${ }^{33}$ On the other hand, "existence" is not an accident because it does not rely on a "substance" to exist. No accident can be by itself without a substance. The case with "existence" is different as "substance" can manage to subsist only through existence. With this analysis the unity of an existent between two moments of change becomes existentially conceivable and real in the world. The "existence" of the changing existent will not vanish but endures throughout the substantial change. Existence becomes the principle of unity and identity. By establishing identity on the principality of "Existence" we realize that neither substance nor accidents can become the ontological foundation for identity. Whatever endures throughout the process of change is nothing more than "existence" itself. Change becomes a single continuum existentially, and can be seen as a gradual renewal only in this ontological context. Otherwise it would be discrete and disconnected. This interpretation of identity is consistent with the existentialist ontology of Mulla Sadra and goes beyond the views of Aristotle and Muslim Peripatetic thinkers who strongly believed in the stability of substance.

Another possible way of dealing with identity is through the distinction between corporeal and incorporeal substances. We understand that this distinction is made on the grounds of their attachment and detachment from "matter". Incorporeal substances are simple; unlike corporeal substances are non-composite existents. Since they are simple and immaterial they are pure actuality. Whatever is pure actuality does not go through change because change is a movement from potentiality to actuality. All incorporeal substances are, therefore, unchangeable and their identity is not in jeopardy. On the other hand, potentiality represents "privation" in the existence of the corporeal substances. In order to triumph over such privation every corporeal substance endeavors to attain its own actuality, "When we spoke of the existence of essential motion throughout bodily nature, which we will explain in detail with proof, we also showed that necessarily any nature, celestial or terrestrial has a perduring rational substance which functions as a principle and also a substance which substantially in process.

\footnotetext{
${ }^{33}$ Mulla Hadi Sabzavari holds a similar view, stating that "One of the negative properties is that 'existence' is neither a substance, because 'substance' is a 'quiddity' which, when it is found in the external world, does not need a 'substance,' while 'existence' is not 'quiddity', nor an 'accident,' when considered in its reality, i.e. the reality of 'existence'." Mulla Hadi Sabzawari (1977). The Metaphysics of Sabzawari, translated from the Arabic by Mehdi Mohaghegh and Toshihiko Izutsu, Delmar, New York: Caravan Books, p. 70. This book is commonly known as Sharh-i manzumah (Commentary on a Philosophical Poem). The commentary, entitled Ghurar alfara'id, is divided into seven headings. Each heading deals with one aspect of Sabzavari's philosophy. They are further divided into chapters and sections.
}

The relation of that substance to this bodily nature is that of perfection to imperfection, of root to branch"34. Change, in this manner, becomes necessary and the existential requirement for every corporeal existent to fulfill itself. But one cannot think about change in incorporeal substances and their identity does not become an issue. Identity becomes problematic only when corporeal substances are investigated.

It is true that Mulla Sadra accepts the existence of incorporeal substances and in al-Asfar, for example, he talks about the differences between incorporeal and corporeal substances. He considers the former to be incorruptible and incapable of destruction. But then what is the difference between this view and that of Muslim Peripatetic thinkers? Has Mulla Sadra established identity on a stable and incorporeal substance? Is this view in contradiction with the doctrine of transubstantial change? The distinction between incorporeal and corporeal substances is not a reference to two different and separate realities, one ideal and the other material. Mulla Sadra's ontology does not accept metaphysical dualism. The incorporeal substances do not have their own reality in the way the ideal forms of Plato have it. They are merely ideas in God's knowledge and for this reason they are incapable of destruction, “... whatever is known to God, the Exalted, [in his exemplary idea] cannot be eliminated; that is to say, the knowledge of God, the Exalted, cannot be changed"35. Sabzavari in his commentary on Mulla Sadra's notion of rational or incorporeal substance confirms that these substances are subtle realities, "whose stable aspect depends on the lords of species"36. Incorporeal substances are not "real" in the sense they do not exist in the temporal and changeable world. Their existence is ideal in God's knowledge. Since God's knowledge does not change the incorporeal substances, these ideas remain stable. They are exposed to change only when they are externalized and attached to matter in the temporal world. Their attachment with matter transforms them radically into corporeal substances and composite of potentiality and actuality. There is no incorporeal substance in the temporal world. Whatever we find is the combination of matter and form, potentiality and actuality and consequently changeable. For this reason, the possibility of establishing identity on incorporeal substance in the world of material existence is doomed to failure. One can talk about identity of the incorporeal substances when they are found as ideas in the mind of God; otherwise nothing in the world (outside the mind of God) is stable.

Transubstantial change is applicable to all kinds of corporeal substances including human existence. Human existence is also in constant substantial change. For this reason, it is impossible to establish the notion of personal identity on "substance". This is the ontological position of Mulla Sadra and he believes that the idea of personal identity is fictitious and based on "resemblance" rather than stability of substance because every individual is essentially in constant renewal, "Because of the similarity of the forms which constituted the oneness of simple body [body in the abstract], it has been assumed that there is some single and stable form other than renewed. But this is not so because it is one by definition and signification, but not numerically" ${ }^{37}$. There is a distinction between two forms of an

\footnotetext{
${ }^{34}$ Mulla Sadra, al-Asfar, 3, stage 7, chapter 25, p. 154.

${ }^{35}$ Mulla Sadra, al-Asfar, 3, stage 7, chapter 26, p. 170.

${ }^{36}$ See Subzavari's commentary in footnote (5), (al-Asfar, 3, stage 7, chapter 25 , p. 154). "Lords of species" is a term also used by Suhrawardi, which are archetypes correspond to Ibn'Arabi's notion of immutable ideas (al-a'yan al-thabita).

${ }^{37}$ Mulla Sadra, al-Asfar, 3, stage 7, chapter 19, p. 101.
} 
individual human existence at two moments of substantial change. The second form, which has become actual, is different from the previous form. As a consequence of this, there is nothing but constant renewal and flux. How can we then establish personal identity? With thinking of transubstantial change without considering the principality of "Existence" there is no room for personal identity because nothing remains unchangedable and at every moment a new form is created. Even the Cartesian solution is of no assistance to us. Its notion of identity depends on our imagination while conceiving similarity of the forms. By relying on imagination to produce a notion without corresponding to anything outside the mind, personal identity becomes unreal. But we can find the ground for it existentially. We argue that although a human being is substantially in process and change constantly, she/he has an existential unity. The identity and unity of every individual lies in "existence". Transubstantial change is a continuous movement of existence, which preserves identity and difference in itself. Existence and not substance provides persistent identity within the changing individual.

\section{REFERENCES}

Aristotle (1995a). Categories. Complete works of aristotle. Princeton, NJ: Princeton University Press.

Aristotle (1995b). De interpretatione. Complete works of aristotle. Princeton, NJ: Princeton University Press.

Aristotle (1995c). Complete works of aristotle. Princeton, NJ: Princeton University Press.

David, G. (1984). Parmenides of elea, fragments, a text and translation with an introduction. Toronto, Buffalo, London: University of Toronto Press.

Mulla, H. S. (1977). The metaphysics of sabzawari. New York: Caravan Books.

Mulla, S. (1981). Al-shawahid al-rububiyyah. Tehran: University Publication Centre.

Mulla, S. (1999a). Al-asfar al-Arba'a. Beirut: Dar Ihya' al-Turath al-'Arabi.

Mulla, S. (1999b). Al-mazahir al-ilahiyya. Tehran: Sadra Islamic Philosophy Research Institute (SIPRIn) Publication.

Mulla, S. (2010). Al-asfar. London: ICAS Press.

Mulla, S., \& Muhammad b. Ibrahim (Sadr al-Din) Shirazi (1992). Almasha'ir. New York. 